今 井敏信

1. まえがき襟裳火山砂と云5のは、禁裳岬 附近の海岸段丘上で典型的に見られる黄褐色を呈 する洪嫧火山灰で，小笠原氏1によつて命名され たものである。ての後坂口氏2も静内及び富川附 近で，火山性地出物として注意したが，未だ日高
いる。前記ヤンケベッ面上のものは, 著くく開析 された小越面上に再堆靕している部分も見られ， 草木のない襟裳火山砂特有の明るい黄褐色の著し い景観を呈している。

この火山砂は襟裳岬から西方の日高沿岸にも公 沿岸全域にわたつての組䋨的な研究は なく, 凤その噴出源についても従来は 未詳とされて来た。

筆者は1957年及び1958年夏，襟裳岬 〜富川間の地形面を調査しそれらの分 類対比を行つた際に，前記洪皘火山灰 及び噴出源の知られている沖積火山灰 層か，厸く分布堆嫧している事を明ら

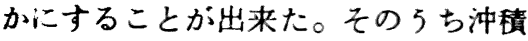
火山灰については，山田氏3放甿に 研究され夫々の膹出源をを明らかにさ れている。

此処では筆者が日高沿岸の地形発達 史4の構成で取り扱った祭裳火山砂心

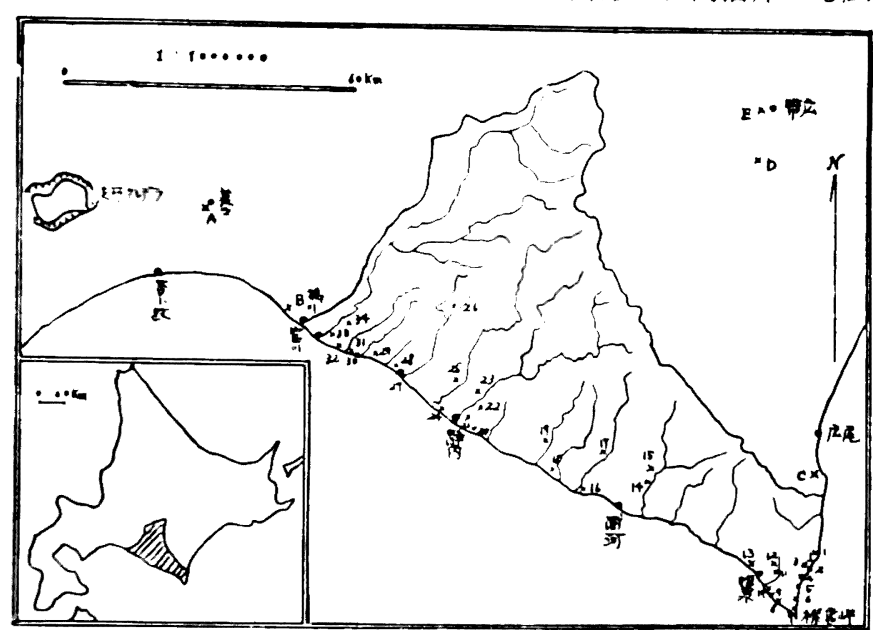

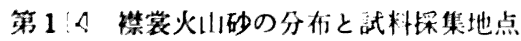
ついて，その調査結果及びその後の資料をも加之 て，分布及び堆䞍物の内容から噴出源について言 及し，当時の地形面との望係及び第四紀地形年 に㧍汁る意義心ついて考察する。

この研究に当り終始御指導下さった, 東北大学 理学教室雷田芳郎教授, 藤原健藏助手, 重鉱物に ついて種々御指導頂いた，東北大学教養部八木健 三教授, 理学部岩石学教室千藤助教授, 化石林そ の他について御教示下さつた北海道大学理学部地 鉣教室勝升義婎講師に厚く御礼申し上げる。

2. 分布之首序此の襟裳火山は, 襟裳岬附近 の60m内外及び 15 20m内外の海岸段斥（ヤンケ ベッ面及び小越面5)）上に最む典型的に堆皎して

く分布し，㯲裳附近のヤンケペッ面及び小越面に 相当する海岸段丘面上，諸汀川の沿岸に発達する 比帛10m〜20m内外の禹位河岸段丘面上に堆皘し ている。それらの分布及び試料採集地点を第 1 区 に示した。第 2 図はこれら試料採集地点の中の 主要なものの柱状困である。

野外調查では，冲積世の火山灰層とは異なり， 洪质世のものである為に, $300 \mathrm{~m}$ 以上の開析の進 んた侵蝕面上又は尾根の鞍部等に扣いても認めら れず，此較的良好に保存されている上記段丘面上 にしか認められなかった。文場所によっては雯々 堆皘状態が乱されており, 調䍒にはかなりの困䨀 が伴なった。

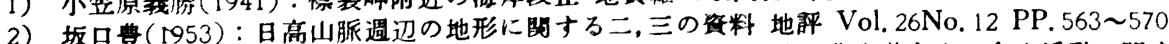

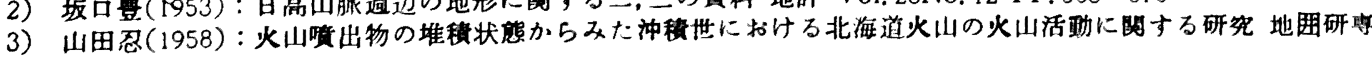
壀 No. 8

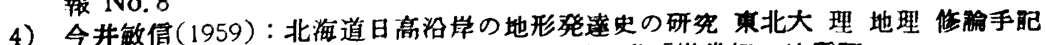

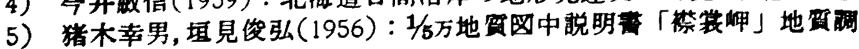


第2図柱状眼

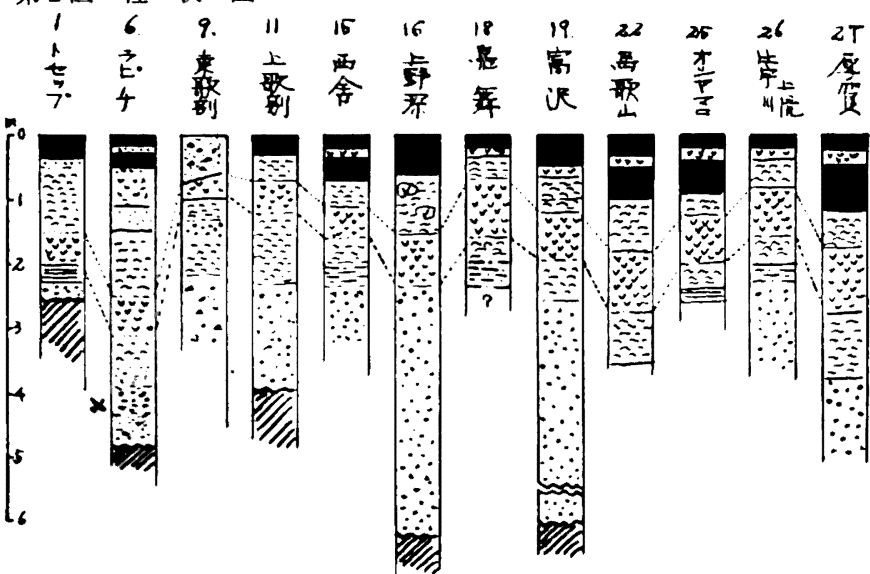

来

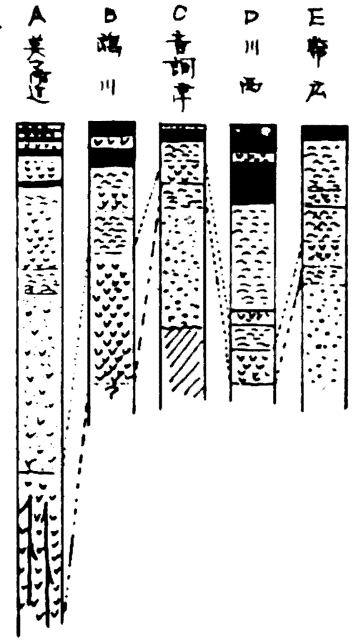

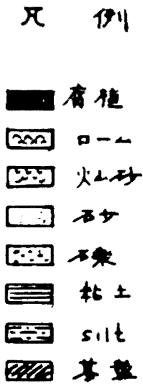

これらの各地点に打汁り襟裳火山砂は，外観上: 触感上類似して扣り，襟裳岬力ら畾方富川方面に 至る程層學を增して行く。（第2龱）

典:この火山砂屏は，苫小牧方面に行くに街い 㾍厚と粒度が大となり，勝井氏6によって支第降 下怪石堆積物と命名された毛のに連繶している。

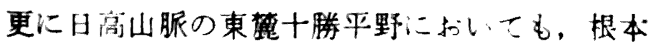
氏等7 は冲皘面を除く各段丘面上:，かなり等い “浮石層心の分布を報告しており，瀬尾氏等8) 同㥞の止に注意している。最近ではこれら十勝平 野南部の淇皘火山兏厥について，禁裳火山砂の分 价之関浬して貝塚氏9"が報告されている。筆者毛
1959年夏の調査によって, 音調津, 公尾, 大樹, 川西等の段斥面上に, 日高沿岸でみられたと同様の襟裳火 山砂が堆積している事を明らかにす る束か出来た。参考の為にそれらの 杜状困を第 2 図に示した。

富川以西については，勝井氏10)11) 金森氏12)等により詳細に研究されて いるので省略する。上述の如く日高 沿岸に分布する洪積火山灰は地形面 との関係, 層序, 層厚の変化等の点 から同時に堆積した同一噴出源を有 するものと認められるが,これらの 粒度組成及び重鉱物組成について次 に述べる。

\section{3. 粒度組成}

第1目で示した各地点より採集し た試料を，天日及び乾燥機で乾燥さ せた後，4分法により20grを秤量し $\therefore 16 \mathrm{~mm}$ 以下を水節し去った後, 蒸 発血に入れて乾喿機で乾懆し、Tyler の標準箅で, 粒経>2. 2 1, 1 1/2, $1 / 2 \sim 1 / 4,1 / 4 \sim 1 / 8,1 / 8 \sim / 16,1 / 16<$ の 7 階极に箱別し，それらの重量比 を求め第1表に示した。概観与れれば 襟裳岬より苗方に至る程 粒徍が大

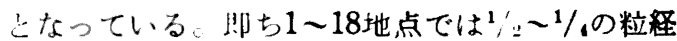
のものが尼倒的に多いが, 19２3地点では2〜1, $1 \sim 1 / 2,1 /: 1 / 1$, の更のが略々平均して多くな ク, 24～30地点で:2〜 1の粒径のものが, 31〜 34 地点では粒径 2 以上のものがやや多くなってい

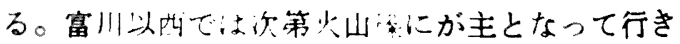
，美々附近では前記支笏軽石堆皘物となっている。

このよ5に西方程粒径が大きなっていると云 ら占は，ての噴出源に近つくく事を意味している。 更にこ机ら粒度分析を試みた試料について重鉱物 組成を調ぺた。

\section{4. 重鉱物組成}

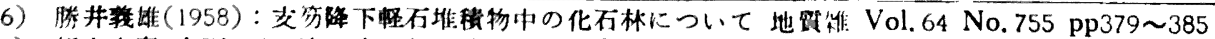

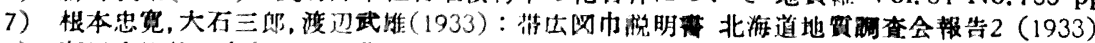

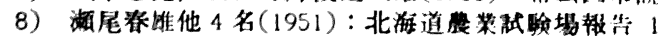

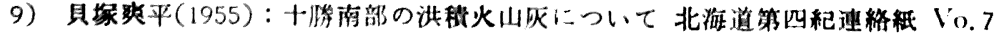

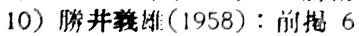

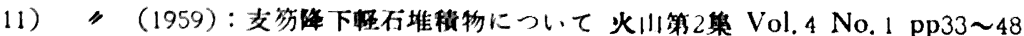

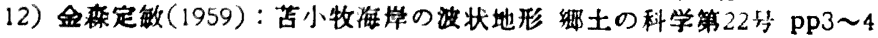


第 1 表 粒 度 組 成

\begin{tabular}{|c|c|c|c|c|c|c|c|c|c|}
\hline 番号 & 位 & 置 & $>2^{\mathrm{mm}}$ & $2 \sim$ & $1 \sim 1 / 2$ & $1 / 2 \sim 1 / 4$ & $1 / 4 \sim 1 / 81$ & $/ 8 \sim 1 / 16$ & $1 / 16<$ \\
\hline 1 & r $七$ & ッ プ & 2.0 & 18.0 & 14.0 & 49.5 & 7.5 & 3.5 & 5.5 \\
\hline 2 & ラ & $ヒ$ & 0 & 6.0 & 9.7 & 60.0 & 13.7 & 6.6 & 4.0 \\
\hline 3 & シトマ: & マン川右岸 & 0 & 1.7 & 1.7 & 53.3 & 16.3 & 14.3 & 12.8 \\
\hline 4 & 苫 & 別 & 0 & 2.3 & 9.4 & 65.5 & 10.8 & 3.3 & 8.7 \\
\hline 5 & $"$ & $"$ & 0.5 & 4.0 & 9.0 & 64.0 & 14.3 & 3.0 & 5.2 \\
\hline 6 & ク $\checkmark$ & ソ沢右 & 0 & 1.5 & 5.0 & 68.8 & 16.3 & 2.5 & 6.4 \\
\hline 7 & 小 & 越 & 0 & 1.2 & 7.5 & 80.9 & 5.7 & 1.5 & 3.2 \\
\hline 8 & 坂 & & 0 & 2.3 & 3.2 & 69.0 & 12.2 & 3.3 & 10.2 \\
\hline 9 & 東 & 別 & 0.2 & 1.4 & 9.5 & 71.3 & 9.7 & 1.8 & 6.1 \\
\hline 10 & $"$ & $"$ & 0.5 & 5.0 & 6.5 & 58.0 & 14.5 & 6.0 & 9.5 \\
\hline 11 & 上 & 別 & 0 & 2.8 & 5.0 & 63.6 & 16.6 & 5.0 & 7.0 \\
\hline 12 & 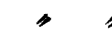 & $"$ & 0 & 3. 0 & 8.5 & 71.5 & 8.1 & 2.8 & 6.0 \\
\hline 13 & サ ッ & = & 1.5 & 3.5 & 6.8 & 69.0 & 12.0 & 8 & .2 \\
\hline 14 & 西 & 秀 & 0.5 & 3. 2 & 6.5 & 56.0 & 22.7 & .0 & 3. 1 \\
\hline 15 & $"$ & $"$ & 0 & 3.9 & 13.5 & 65.1 & 8.8 & 4.5 & 4.0 \\
\hline 16 & 萩 & 恰 & 0.9 & 9.5 & 14.4 & 53.4 & 12.3 & 0 & 3.5 \\
\hline 17 & 上 & 浫 & 2.0 & 14.5 & 16.5 & 53.0 & 5.5 & 5 & 5. \\
\hline 18 & 塋 & 舞 & 1.5 & 18.5 & 13.0 & 59.0 & 4.5 & .5 & 1.0 \\
\hline 19 & 富 & 讯 & 0.5 & 22.5 & 22.5 & 25.4 & 4.1 & 21.5 & 3.5 \\
\hline 20 & 静 & 内 & 7.0 & 43.5 & 16.1 & 27. & 2.5 & 1.8 & 1.5 \\
\hline 21 & 馬 & 山 & 7.3 & 51.0 & 16.5 & 21.5 & 1.5 & 1.2 & 1.0 \\
\hline 22 & $"$ & $"$ & 10.2 & 27.1 & 19.0 & 34.4 & 3. 0 & 1.7 & 4.6 \\
\hline 23 & 御 & 園 & 2.0 & 10.5 & 12.5 & 43.5 & 13.5 & .7 & 9.5 \\
\hline 24 & 浦 & 里 & 4.5 & 31.5 & 21.1 & 33.5 & 2.5 & 2.0 & 4.9 \\
\hline 25 & オシ & $+\nabla=$ & 3.4 & 43.5 & 23.2 & 23.0 & 11.0 & 0.7 & 5.2 \\
\hline 26 & 比宇川 & 川上流 & 5.1 & 40.8 & 18.9 & 28.1 & 2.5 & 2.0 & 2.5 \\
\hline 27 & 厚 & 賀 & 15.2 & 45.2 & 18.1 & 14.7 & 1.7 & 1.7 & 3.4 \\
\hline 28 & 賀 & 张 & 19.2 & 32.8 & 24.8 & 17.5 & 2.6 & 1.5 & 1.6 \\
\hline 29 & 清 & 里 & 7.7 & 30.1 & 19.4 & 27.3 & 4.1 & 2.4 & 9.0 \\
\hline 30 & 豊 & 犝 & 16.2 & 35.8 & 15.6 & 19.0 & 3.1 & 3.5 & 6.8 \\
\hline 31 & 門 & 別 & 48.2 & 18.5 & 9.9 & 15.0 & 2.4 & 2.4 & 3.6 \\
\hline 32 & 富 & 川 & 42.9 & 33.4 & 12.6 & 7.3 & 0.4 & 0.7 & 2.7 \\
\hline 33 & " & $"$ & 51.5 & 26.5 & 10.2 & 8.3 & 0.7 & 0.8 & 2.0 \\
\hline 34 & シ ラ & ウ 沢 & 29.5 & 26.7 & 17.0 & 22.9 & 1.3 & 1.0 & 1.6 \\
\hline
\end{tabular}

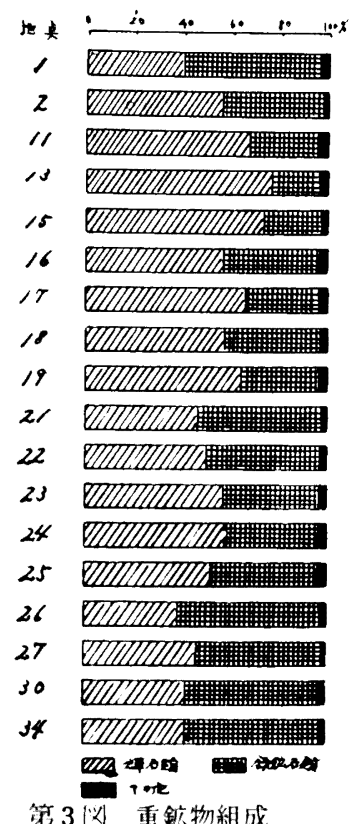

分離した。そして分離した重鉣物の 250〜300粒について，各種鎕物に識 別し，各々の個体\%を求めた。

その結果各種鉣物を，战石類，鉄 鈗石類，その他として第 3 四に示し た。輝石類は大部分紫蘇辉石で普通 此石は少い。鉄鉱石類は大部分が磁 鉄鉱でチタン鉄鉱，赤鉄鉱は少量で ある。その他の鉣物の中には角閃石 黑需母なとが含まれている。又轰鉱 物としては, 軽石粒, ガラスが大部 分を占め, 石英, 長石も少量入って いる。

\section{5. 喷出源及ひその時代}

従来火山灭，関東口ーム等について行われた重 鉱物組成の研究方法は2，3紹介されているが，筆 者は次のような方法を取った。

先つ前記粒度分析を行った試料を取り, 比重2. 9 の重液で重鉱物を分離した。粒度の各階級によ り, その重鉣物内容も比率も巽なっているので, 一応 2 個の試料について全階䄲の重鉱物を分離し て検討した結果, 分離操作, 検鏡, 鉱物内容等の 点から $1 / 4 \sim 1 / 8$ の階級のものが適当である事が判 明したので, 各試料についてこの粒售の重鉱物を
以上述へてて来た事を絵合すると, 従来喷出源が 未詳とされて来た襟裳火山砂は, 日高沿岸の憵低 二段の海岸段丘及び高位河岸段丘上に堆積してお。 り，その噴出源はWürm 水期後半において活動 した所の支第火山13)である掉が明らかになった。 勝井氏が支第降下軽石堆皘物と称しているものと 襟裳火山砂とは同一物であり，繁密に云えば交架 火山灰と称されるべきものである。

この洪積火山灰の堆皘状態から考察すると, 扡 出された後偏西風によって連搬されて降下し, 空 
中で十分な分級作用を受けた事は明らかである。 若しも降下した後流水の作用を受けて堆積したも のとするならば，第2㘡で示した柱状㘡で見られ るように, ロ一ム層の間に堆皘している事, 重鉣 物組成でみられるように，上流地域に由来すると 考えられる鉱物成分が見られない事等は，解釈に 苦しむ所である。

襟裳火山砂は日高沿岸に扣いて, 既述の高低二 段の海岸段丘層, 高位河岸段丘層を被輹して いる点から考えると，これらの火山灰が堆積した 後は，低位海岸段丘，高位诃岸段丘を掩５よ5な 海進があったとは帣えられない。この火山成降下 の絶対年令は, 美々附近の化石林の跨化木の $\mathrm{C}^{11}$ 法に上る年代決定が北大泉诚比によって行われ，

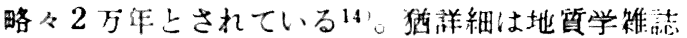
に発表される筈でする。

又襟裳岬附近の小越面儿打いては，襟裳火山砂 はマンモス象(Mammonteus primigenius Bllu-

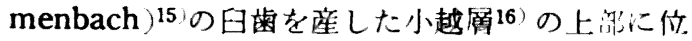
置している(第1図)。凑氏(7)はこのマンモス象日 齿を, 第 4 水期を示準するものと考えている。従 って祭裳火山砂の降下の年代は，これにやや扰く れ Wiirm 氷期徯半と考之る事は, 絶対作数の点 から考へても琵りのないものと考えられる。

この襟裳火山砂降下の時期を勝井氏 18 ' であって匃候は寒冷であり海退が行われたであろ
ろとして，札幌〜苫小牧低地带において低位段丘 面が河谷によって侵強され，この河谷に沿って支 第軽石流が流下している事を挙げている。然し海 岸段丘と河岸段丘との関係がよく観察される襟裳 岬附近及び厚賀〜門别間に执いては，河川の河口 附近で丁字現象が見られ19)，明らかに地盤の隆起 を示している。従って氷期に伴 5海退もあったで あろらし，それに関連して地盤の隆起も見逃して はならない。

\section{6. むすひ}

日高沿岸の地形発達史の組み立を試みた際に， 地形面対比の keybed として用いた襟裳火山砂に ついて以上述べて来た东をまとめてむすびとす る。

(1) 彷来嗢出㝸末洋とされていた襟裳火山砂は 支笏火山にその噴出源を有するものである事 が判明した。

(2)流水の作用を受けて堆皘したものではなく 降下堆積したものであり，その時期は，絶対 年数の算出からも推定されるよ $5 に ， W u ̈ r m$ 氷期の後半と考えられる。

(3) 地形面対比の key bed とする事が出来, 地 形発達史に扸洔期画定の尺度と出来る。

(4) 十勝平野にも分布して招り, 日高山脈周辺 の地形面の対比が今後の問題として残され に。

14) 勝井義雄氏よりの私镺に上る

15) .Minato, M. (1955): Japanese Jour. Geol. Geogr. 26pp 105 113

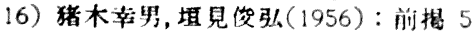

17) Minato. M. (1955): 前揭 15

18) 勝井数婎 (1959)：前揭 11

19) 今井敏俏 (1959)：前揭 4

\section{Erimo Volcanic Sand in Hokkaido. \\ Toshinobu IMAI}

The Erimo sand was named by Dr. Y. Ogasawara in 1941 at Erimo in Hokkaido. In 1957 and 1958, present writer found the Erimo sand distributed widely on the terrace surfaces along the coast of Hidaka.

The volcanic sand of Erimo is deposited on the higher and lower coastal terraces as well as on the higher river terraces along the Hidaka coast. Stratigraphically it continues to the Shikotsu pumice deposit, erupted from the Shikotsu volcano in the late Pleistocene at Bibi and in its neighbourhood. The author examined 34 columnar sections (Fig. 2), and analysed_the grain size and heavy mineral composition (Fig. $3,4)$. According to his observations, the volcanic sand of Erimo has the same origin as the Shikotsu pumice deposit.

An embedded fossil forest was discovered at Bibi and in its neighbourhood, and its absolute age was decided by $\mathrm{C}^{14}$ methods. The volcanic sand of Erimo covers the Mammontius bed correlated with the lower terrace deposit at Ogoshi. The abovementioned relations exit also in the south of Tokachi plain. Consequently it is considered that the terraces of Hidaka coast and Tokachi plain are correlated each other geomorphologically. 